\title{
Commemoration ceremony, Dr. Wissam Al-Hashimi
}

On 12 February 2013 a ceremony was held at the Burlington House, London, to commemorate Dr. Wissam Al-Hashimi who was kidnapped, tortured and brutally killed by terrorists in August 2005, in Baghdad, Iraq.

Dr. Wissam Al-Hashimi was President of the Geological Society of Iraq, the Secretary-General of the Arab Geological Association (AGA) since 1993 and Vice-President of the International Union of Geological Sciences (IUGS) from 1996-2002. A well known engineering geologist with significant experience in underground construction, Dr. Al-Hashimi was invited to contribute to the First International Conference on Sustainable Development and Management of the Subsurface, held at Utrecht, The Netherlands in 2003. His article on 'the underground city of Al-Najaf, Iraq' was recently published in a book: Sustainable Development and Management of the shallow Subsurface. This book was dedicated to Dr. Wissam Al-Hashimi and to his legacy for the global geoscientific community.

At the ceremony, first copies of the book were presented to his widow Mrs. Muatabar Hasan and to his daughters Farah and Balsam Wissam-Al-Hashimi, who attended the ceremony in person together with other family members and friends. The other dignitaries who attended the ceremony include the President of the Geological Society of London, David Shilston, the President of the International Union of Geological Sciences represented by Dr. Eduardo de Mulder, the authors of the book, the cultural attaché of the Iraqi Embassy in the UK and the Editor of Geoscientist magazine, Ted Nield.

David Shilston, President of the Geological Society of London welcomed the delegates and Dr. Robert Hack, co-author of the book, presented some highlights of the book. Dr. Eduardo de Mulder, coauthor of the book and former President of the IUGS, whose term

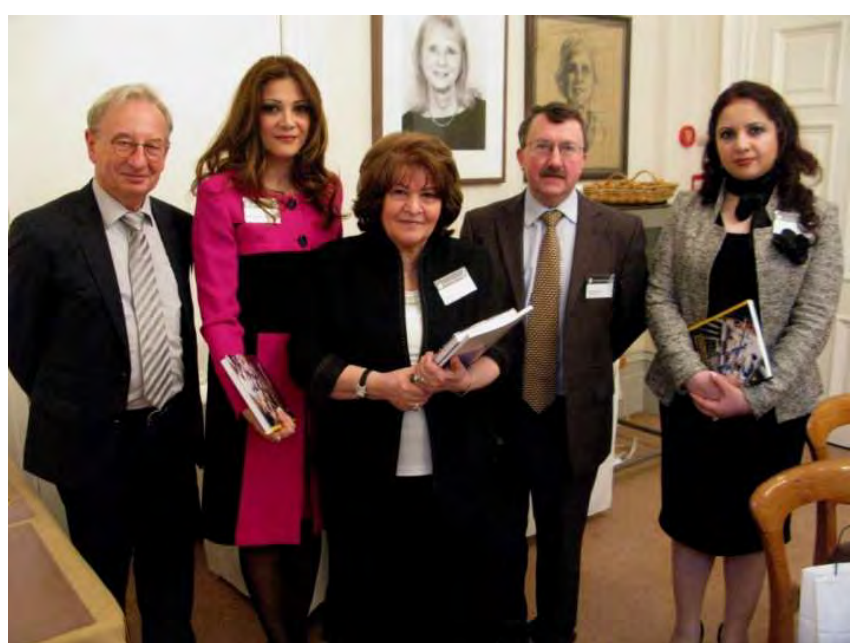

From left to right: Eduardo de Mulder (Director Earth Science Matters Foundation, Miss Balsam Wissam Al-Hashimi (Wissam Al-Hashimi's daughter), Mrs Muatabar Hasan (Wissam AlHashimi's widow), David Shilston (President Geological Society of London), and Ms Farah Wissam Al-Hashimi (Wissam AlHashimi's daughter).

partly overlapped with that of Dr. Al-Hashimi as Vice-President of this organisation recalled his personal observations and the significance of Dr. Al-Hashimi for the global geoscience community. The programme came to an end with the vote of thanks presented on behalf of the Al-Hashimi by Mrs. Muatabar Hasan.

The ceremony was recorded for broadcast on Iraqi National TV. The event was organised by the Geological Society of London, IUGS, the Earth Matters Foundation and by the authors of the book.

\section{CALL FOR PAPERS}

Episodes is a quarterly science and news journal of the International Union of Geological Sciences (IUGS). It focuses on the publication of results of scientific research and other information addressing issues of interest to the global Earth science community. Special emphasis is given to topics involving geological aspects of population growth and economic development and their resulting impacts on or implications for society. As the principal publication of the IUGS, Episodes also carries information about IUGS scientific programs and activities to the extent necessary to communicate effectively with the worldwide IUGS constituency.

Contributions of the following types of manuscripts are solicited:

- Review papers

- News and views

- Letters to editor
- Conference reports

- Book reviews

- Information on training courses (especially those geared to participants from developing countries)

- Noteworthy new publications, including national or regional geological maps

Episodes also invites photos or other images for the front cover. Photos must be of high technical quality and tell an interesting geological story. A color transparency and one color print (at least $9 \mathrm{~cm} \times 12.6 \mathrm{~cm}$ ) are required for submission, which should be supplemented with a short explanatory paragraph (no more than 100 words).

Please address all contributions to: Editor,

Episodes

Email: episodes.editor@gmail.com 